\title{
Brief Study on Microelement Contents in Topsoils of Farmlands in Xuancheng, South Anhui
}

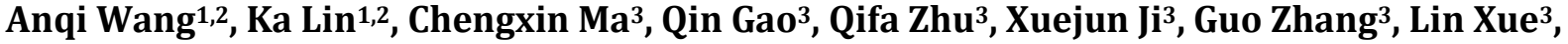 \\ Chaolong $\mathrm{Zu}^{4}$, Chaoqiang Jiang ${ }^{4}$, Jia Shen ${ }^{4}$, Decheng Li ${ }^{*}$
}

\author{
${ }^{1}$ State Key Laboratory of Soil and Sustainable Agriculture, Institute of Soil Science, Chinese Academy of Sciences, Nanjing, China \\ ${ }^{2}$ University of the Chinese Academy of Sciences, Beijing, China \\ ${ }^{3}$ Institute of Tobacco Science, Anhui Agricultural Academy of Sciences, Hefei, China \\ ${ }^{4}$ Wannan Tobacco Co. Ltd., Xuancheng, China \\ Email: aqwang@issas.ac.cn, *dcli@issas.ac.cn
}

How to cite this paper: Wang, A.Q., Lin, K., Ma, C.X., Gao, Q., Zhu, Q.F., Ji, X.J., Zhang, G., Xue, L., Zu, C.L., Jiang, C.Q., Shen, J. and Li, D.C. (2018) Brief Study on Microelement Contents in Topsoils of Farmlands in Xuancheng, South Anhui. Agricultural Sciences, 9, 718-728. https://doi.org/10.4236/as.2018.96050

Received: May 10, 2018

Accepted: June 23, 2018

Published: June 26, 2018

Copyright $\odot 2018$ by authors and Scientific Research Publishing Inc. This work is licensed under the Creative Commons Attribution International License (CC BY 4.0).

http://creativecommons.org/licenses/by/4.0/

\begin{abstract}
The available contents of microelements in the topsoil can influence the yield and quality of flue-cured tobacco. Xuancheng is the dominant tobacco-planting region in Anhui province since 2008. In this paper, the topsoil available $\mathrm{Fe}, \mathrm{Mn}, \mathrm{Cu}$ and $\mathrm{Zn}$ contents of 4197 farmlands mainly under rice-rice rotation and wheat-rice rotation in 2008 and of 124 typical farmlands under tobacco-rice rotation in 2015 in Xuancheng city were analyzed in order to disclose the changes and spatial distributions of these microelements and to instruct the reasonable application of the microelement fertilizers. The results showed that the topsoil average available contents in the farmlands under rice-rice rotation or wheat-rice rotation in 2008 were $105.9 \mathrm{mg} \cdot \mathrm{kg}^{-1}$ for $\mathrm{Fe}$, $19.6 \mathrm{mg} \cdot \mathrm{kg}^{-1}$ for $\mathrm{Mn}, 4.5 \mathrm{mg} \cdot \mathrm{kg}^{-1}$ for $\mathrm{Cu}$, and $3.0 \mathrm{mg} \cdot \mathrm{kg}^{-1}$ for $\mathrm{Zn}$, respectively, increased by $33.14 \%, 64.29 \%, 51.11 \%$ and $36.67 \%$, respectively, compared with those in the $2^{\text {nd }}$ Soil Survey in 1980s, and the historic, once intensive and overall application of microelement fertilizers was attributed to the great increases. The topsoil average available contents in the farmlands under tobacco-rice rotation in 2015 were $31.1 \mathrm{mg} \cdot \mathrm{kg}^{-1}$ for $\mathrm{Fe}, 9.8 \mathrm{mg} \cdot \mathrm{kg}^{-1}$ for $\mathrm{Mn}, 2.1$ $\mathrm{mg} \cdot \mathrm{kg}^{-1}$ for $\mathrm{Cu}$, and $0.3 \mathrm{mg} \cdot \mathrm{kg}^{-1}$ for $\mathrm{Zn}$, respectively, decreased by $70.63 \%$, $50.00 \%, 53.33 \%$ and $90.00 \%$, respectively, compared with those of the farmlands under rice-rice rotation or wheat-rice rotation in 2008, and the net deficiencies in the input and output of microelements were attributed to the significant decreases in the topsoil microelements. It is necessary to monitor the farmlands under tobacco-rice rotation dynamically and in time in order to decide whether applying microelement fertilizers or not.
\end{abstract}




\section{Keywords}

Microelement, Available Content, Topsoil of Farmland, Xuancheng City

\section{Introduction}

Microelements are necessary for the normal growth of the crop [1] [2]. They can influence the physiological metabolism, growth and development, interior quality and economic traits of the flue-cured tobacco [3]-[8], thus lots of attentions have been paid on microelement status in the tobacco-planting farmlands [9]-[14].

Xuancheng city is current dominant tobacco-planting region in Anhui province since the its initial tobacco-planting in the year of 2008 with the current regular planting area of flue-cured tobacco of about $1 \times 10^{4} \mathrm{hm}^{2}$ (constituted by $90 \%$ more of the tobacco-planting area in Anhui province) and yield of flue-cured tobacco leaves of about $1 \times 10^{4} \mathrm{t}$ [15]. However, there is little or no information available on the microelements in the tobacco-planting farmlands in Xuancheng city, thus, in this paper, the data of available $\mathrm{Fe}, \mathrm{Mn}, \mathrm{Cu}$ and $\mathrm{Zn}$ in the farmland topsoils $(0-20 \mathrm{~cm})$ in Xuancheng city from different sources in different periods were used to evaluate the microelement status in order to instruct the reasonable application of the microelement fertilizers.

\section{Methods and Materials}

\subsection{General Situation of the Study Region}

Xuancheng city is located in the south of Anhui province $\left(117^{\circ} 58^{\prime} \mathrm{E}-119^{\circ} 40^{\prime} \mathrm{E}\right.$, $29^{\circ} 57^{\prime} \mathrm{N}-31^{\circ} 19^{\prime} \mathrm{N}$ ) with a total area of $1.23 \times 10^{4} \mathrm{~km}^{2}$, its mean annual sunshine duration, temperature, precipitation, dryness and frost-free period is $1784 \mathrm{~h}$, $15.6^{\circ} \mathrm{C}, 1200-1500 \mathrm{~mm}, 0.68-0.90$ and $240 \mathrm{~d}$, respectively; its landform is complex and diverse, mountains, hills and valley basins are interlaced in the south with a mean altitude of $1200-1800 \mathrm{~m}$, hills and downlands are distributed in the middle with a mean altitude of $15-100 \mathrm{~m}$, while alluvial plains are dominant in the north with a mean altitude of $7-12 \mathrm{~m}$. Most farmlands in Xuancheng city are currently under the rotation of rice-rice, wheat-rice or tobacco-rice, the tobacco compound fertilizer contains $\mathrm{B}$ and $\mathrm{Zn}$ but without accurate formula on microelements [16].

\subsection{Information of Topsoil Samples of Farmlands}

The data of topsoil available $\mathrm{Fe}, \mathrm{Mn}, \mathrm{Cu}$ and $\mathrm{Zn}$ of farmlands were obtained from the three sources: 1) the $2^{\text {nd }}$ National Soil Survey conducted in $1980 \mathrm{~s}$ (without information of the sample sites), 2) data of 4197 farmlands obtained in the Soil Testing and Formulated Fertilization Project surveyed in 2007 (green dots in Figure 1), and 2) data of 103 typical tobacco-planting farmlands surveyed in 2015 (red dots in Figure 1). 


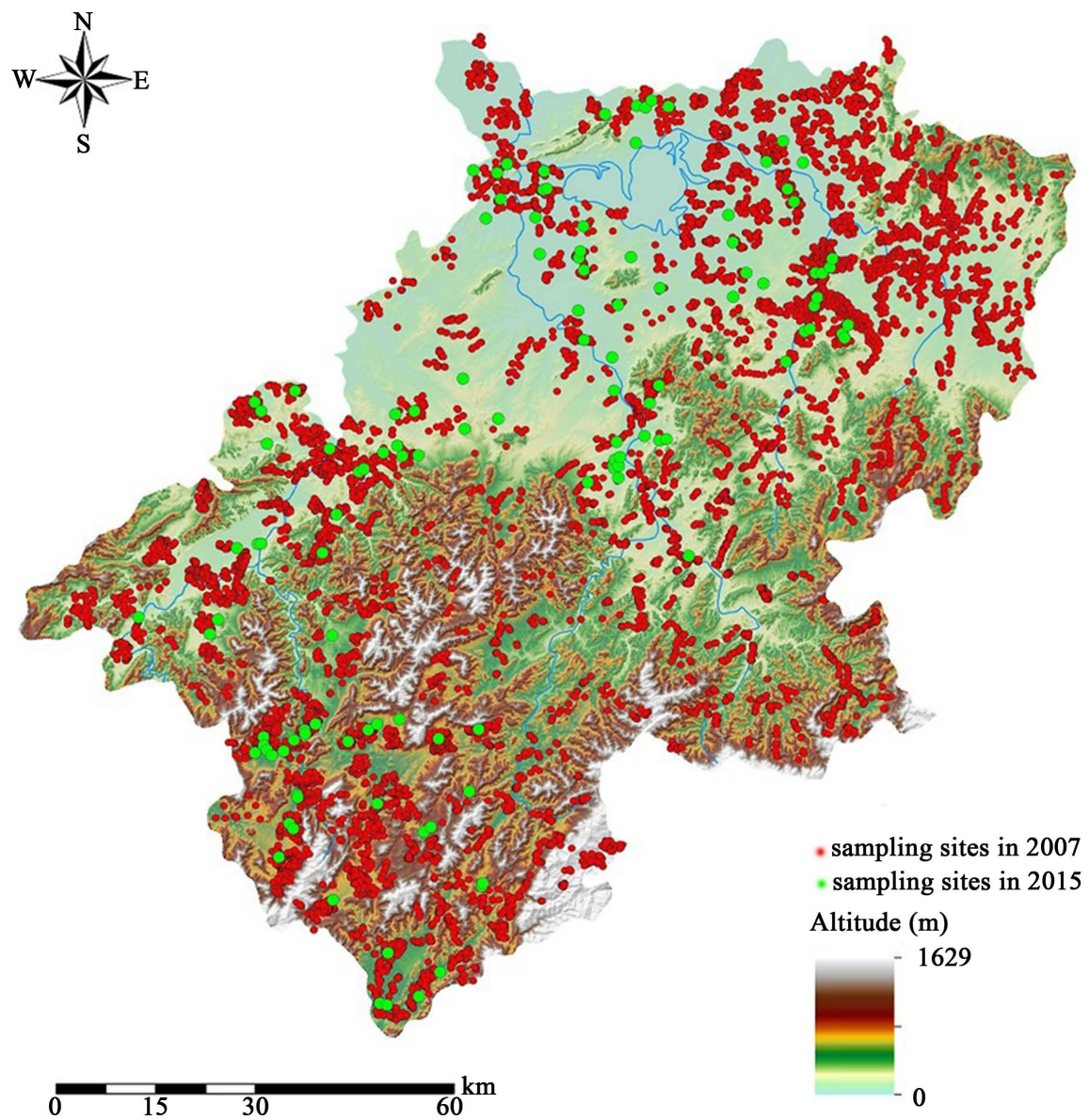

Figure 1. Spatial distribution of topsoil sampling sites of farmlands in Xuancheng.

The typical tobacco-planting farmlands were determined according to the database of tobacco farmers of Wannan Tobacco Ltd. Company in 2015 in which (see Figure 1 and Table 1), these farmlands were selected from different model tobacco farmers who are good in tobacco planting and had the planting area of 2 $\mathrm{hm}^{2}$ or more.

The random multipoint method was used for sampling the topsoil $(0-20 \mathrm{~cm})$ in each typical farmland in 2007 and 2015. Soil samples were air dried, ground and passed $0.25 \mathrm{~mm}$ sieve, then available $\mathrm{Fe}, \mathrm{Mn}, \mathrm{Cu}$ and $\mathrm{Zn}$ were measured by atomic absorption spectrophotometer after extracted by DTPA [17] [18].

\subsection{Classification of Soil Available Fe, $\mathrm{Mn}, \mathrm{Cu}$ and $\mathrm{Zn}$}

Table 2 is the simplified grading standards of available $\mathrm{Fe}, \mathrm{Mn}, \mathrm{Cu}$ and $\mathrm{Zn}$ for the typical flue-cured tobacco planting soil according to the original standards by combing "very low grade" into "low grade" and "very high grade" into "high grade" [1].

\subsection{Data Processing and Thematic Mapping}

Data were analyzed with Microsoft Excel 2013 and IBM Statistics SPSS 20.0, the 
Table 1. Regional distribution of topsoil samples of typical tobacco planting farmlands in Xuancheng.

\begin{tabular}{cccccc}
\hline Region & $\begin{array}{c}\text { Xuanzhou } \\
\text { district }\end{array}$ & $\begin{array}{c}\text { Langxi } \\
\text { county }\end{array}$ & $\begin{array}{c}\text { Jingde } \\
\text { county }\end{array}$ & $\begin{array}{c}\text { Jing } \\
\text { County }\end{array}$ & Total \\
\hline 2007 sample numbers & 919 & 914 & 1028 & 1321 & 4197 \\
2015 sample numbers & 46 & 27 & 27 & 24 & 124 \\
\hline
\end{tabular}

Table 2. Simplified classification of soil available $\mathrm{Fe}, \mathrm{Mn}, \mathrm{Cu}$ and $\mathrm{Zn}$.

\begin{tabular}{ccccc}
\hline Grade $\left(\mathrm{mg} \cdot \mathrm{kg}^{-1}\right)$ & Available Fe & Available $\mathrm{Mn}$ & Available $\mathrm{Cu}$ & Available $\mathrm{Zn}$ \\
\hline Low & $<4.5$ & $<5$ & $<0.2$ & $<0.5$ \\
Middle & $4.5-10$ & $5-15$ & $0.2-1$ & $0.5-1$ \\
High & $>10$ & $>15$ & $>1$ & $>1$ \\
\hline
\end{tabular}

spatial distribution of topsoil samples was mapped on the platform of Esri Arc-GIS 10.3.

\section{Results and Discussions}

\subsection{General Statistics of Topsoil Available Fe, $\mathrm{Mn}, \mathrm{Cu}$ and $\mathrm{Zn}$ in 2007}

Table 3 shows the statistic information of topsoil available $\mathrm{Fe}, \mathrm{Mn}, \mathrm{Cu}$ and $\mathrm{Zn}$ of farmlands in Xuancheng surveyed in 2007.

For topsoil available Fe, it ranged from the low grade to the high grade in total Xuancheng city, also ranged from the low grade to the high grade in Xuanzhou district, but ranged from the middle grade to the high grade in Langxi county and Jing county, ranged in the high grade in Jinde county. For topsoil available $\mathrm{Mn}$ and $\mathrm{Zn}$, they ranged from the low grade to the high grade in total Xuancheng city, also ranged from the low grade to the high grade for all its jurisdictions. For topsoil available $\mathrm{Cu}$, it ranged from the low grade to the high grade in total Xuancheng city, it also ranged from the low grade to the high grade in $\mathrm{Xu}$ anzhou district and Jing county; but ranged from the middle grade to the high grade in Langxi county and Jingde county.

\subsection{Evaluation of Contents of Topsoil Available Fe, $\mathrm{Mn}, \mathrm{Cu}$ and $\mathrm{Zn}$ in 2007}

Table 4 shows the sample number distribution in various grades of topsoil available $\mathrm{Fe}, \mathrm{Mn}, \mathrm{Cu}$ and $\mathrm{Zn}$.

Table 4 shows that to the whole Xuancheng city, only $4(0.10 \%)$ and 11 $(0.26 \%)$ of the topsoil samples were in the low and middle grades of available Fe, respectively, only $293(6.98 \%)$ and $1483(35.34 \%)$ of the topsoil samples were in the low and middle of available $\mathrm{Mn}$, respectively, only 7 (0.17\%) and 71 (1.69\%) of the topsoil samples were in the low and middle grades of available $\mathrm{Cu}$, respectively, only $28(0.67 \%)$ and $111(2.64 \%)$ of the topsoil samples were in the low 
Table 3. Statistic information of topsoil available $\mathrm{Fe}, \mathrm{Mn}, \mathrm{Cu}$ and $\mathrm{Zn}$ of farmlands in Xuancheng in $2007\left(\mathrm{mg} \cdot \mathrm{kg}^{-1}\right)$.

\begin{tabular}{ccccccc}
\hline \multicolumn{2}{c}{ Microelement contents } & $\begin{array}{c}\text { Xuanzhou } \\
\text { district }\end{array}$ & $\begin{array}{c}\text { Langxi } \\
\text { county }\end{array}$ & $\begin{array}{c}\text { Jingde } \\
\text { county }\end{array}$ & $\begin{array}{c}\text { Jing } \\
\text { county }\end{array}$ & Total \\
\hline \multirow{2}{*}{$\mathrm{Fe}$} & Range & $1.7-541.8$ & $6.4-80.3$ & $10.3-243.4$ & $5.7-102.8$ & $1.7-541.8$ \\
& Mean/S.D. & $210.1 / 139.1$ & $60.5 / 9.5$ & $127.5 / 29.8$ & $48.3 / 15.2$ & $105.9 / 92.6$ \\
$\mathrm{Mn}$ & Range & $0.5-189.3$ & $3.3-44.4$ & $0.6-61.5$ & $1.2-46.5$ & $0.5-189.3$ \\
& Mean/S.D. & $18.4 / 18.4$ & $27.4 / 5.0$ & $14.2 / 9.8$ & $19.1 / 11.4$ & $19.6 / 12.9$ \\
$\mathrm{Cu}$ & Range & $0.4-8.3$ & $0.1-12.3$ & $0.1-27.0$ & $0.1-48.6$ & $0.1-48.6$ \\
& Mean/S.D. & $4.0 / 1.6$ & $3.6 / 1.0$ & $2.6 / 1.5$ & $7.0 / 4.1$ & $4.5 / 3.1$ \\
$\mathrm{Zn}$ & Range & $0.1-10.5$ & $0.3-4.0$ & $0.3-21.6$ & $0.1-43.0$ & $0.1-43.0$ \\
& Mean/S.D. & $2.4 / 1.3$ & $2.0 / 0.5$ & $2.5 / 1.1$ & $4.8 / 3.8$ & $3.0 / 2.6$ \\
\hline
\end{tabular}

Table 4. Numbers of farmlands under different grades of topsoil available $\mathrm{Fe}, \mathrm{Mn}, \mathrm{Cu}$ and $\mathrm{Zn}$ in Xuancheng in 2007.

\begin{tabular}{ccccccccccccc}
\hline & \multicolumn{3}{c}{ Available Fe } & \multicolumn{3}{c}{ Available Mn } & \multicolumn{2}{c}{ Available Cu } & \multicolumn{2}{c}{ Available Zn } \\
\cline { 2 - 11 } Region & Low & Middle & High & Low & Middle & High & Low & Middle & High & Low & Middle High \\
\hline Xuanzhou & 1 & 3 & 919 & 91 & 419 & 413 & 0 & 11 & 912 & 16 & 38 & 869 \\
Langxi & 3 & 0 & 914 & 1 & 5 & 911 & 1 & 1 & 915 & 2 & 22 & 893 \\
Jingde & 0 & 0 & 1028 & 106 & 578 & 344 & 3 & 56 & 969 & 2 & 24 & 1002 \\
Jin & 0 & 8 & 1321 & 95 & 481 & 753 & 3 & 3 & 1323 & 8 & 27 & 1294 \\
Total & 4 & 11 & 4182 & 293 & 1483 & 2421 & 7 & 71 & 4119 & 28 & 111 & 4058 \\
\hline
\end{tabular}

and middle grades of available $\mathrm{Zn}$, respectively. The above data suggest most of the farmlands were sufficient in $\mathrm{Fe}$ and $\mathrm{Cu}$ nutrients, no need for applying $\mathrm{Fe}$ and $\mathrm{Cu}$ fertilizers, but a few of farmlands in Xuanzhou district (91 farmlands, $9.86 \%$ of its total farmlands), Jingde county (106 farmlands, $10.31 \%$ of its total farmlands) and Jing county (95 farmlands, $7.15 \%$ of its total farmlands) were in $\mathrm{Mn}$ and $\mathrm{Zn}$ deficiency and should applying $\mathrm{Mn}$ and $\mathrm{Zn}$ fertilizer.

Figure 2 shows the distribution of the available $\mathrm{Mn}$ and $\mathrm{Zn}$ in the farmland topsoil in Xuancheng, the deficiency of $\mathrm{Mn}$ and $\mathrm{Zn}$ mainly were located in the northeast region, and $\mathrm{Mn}$ deficiency also sporadically existed other regions.

The reason for insufficient $\mathrm{Mn}$ and $\mathrm{Zn}$ nutrients in the northeast farmlands is that these farmlands are the historically longest for rice-planting, and the paddy soils are derived from the alluvial sediments of weathered granites and metamorphic rocks, soil texture is coarse with more sand particles ${ }^{1}, \mathrm{Mn}$ and $\mathrm{Zn}$ is easily leached down from the topsoils during the season of rice-planting [1] [19], so easily resulted in $\mathrm{Mn}$ and $\mathrm{Zn}$ deficiency under condition of no or insufficient $\mathrm{Mn}$ fertilizer supply. The deficiency of $\mathrm{Mn}$ and $\mathrm{Zn}$ can worsen the quality of ${ }^{1}$ Soil Survey Office \& Soil Fertilization Station of Xuanzhou. Xuanzhou Soil, 1987. 

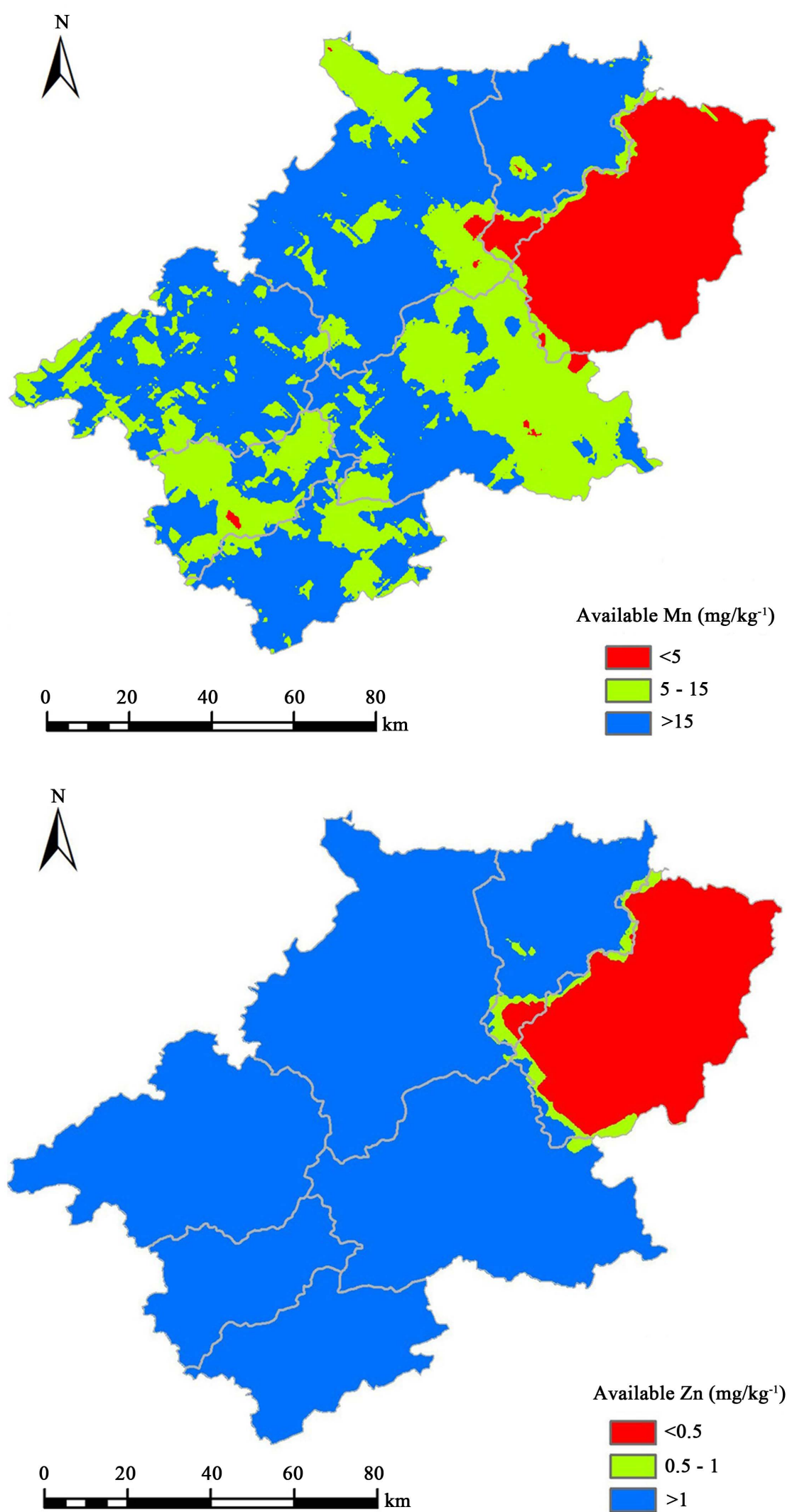

Figure 2. Spatial distribution of available $\mathrm{Mn}$ and $\mathrm{Zn}$ in topsoil of farmland in Xuancheng. 
leaves, even cause the wither and death of tobacco [20], so $\mathrm{Mn}$ and $\mathrm{Zn}$ fertilizers should be applied for these $\mathrm{Mn}$ or $\mathrm{Zn}$ deficiency farmlands.

\subsection{General Statistics of Tobacco-Planting Topsoil Available Fe, Mn, Cu and Zn in 2015}

Table 5 shows the statistic information of topsoil available $\mathrm{Fe}, \mathrm{Mn}, \mathrm{Cu}$ and $\mathrm{Zn}$ of tobacco-planting farmlands in Xuancheng surveyed in 2007.

For tobacco-planting topsoil available $\mathrm{Fe}$, ranged from the middle grade to the high grade in total Xuancheng city, also ranged from the middle grade to the high grade in Xuanzhou district, but ranged in the high grade in Langxi county, Jingde county and Jing county. For tobacco-planting topsoil available $\mathrm{Mn}$, it ranged from the low grade to the high grade, also ranged from the low grade to the high grade in Xuanzhou district, Jingde county and Jing county, ranged from the middle grade to the high grade in Langxi county. For tobacco-planting topsoil available $\mathrm{Cu}$, it ranged from the middle grade to the high grade in total Xuancheng city, also ranged from the middle grade to the high grade in all its jurisdictions. For tobacco-planting topsoil available $\mathrm{Zn}$, it ranged from the low grade to the high grade in the total Xuancheng city, also ranged from the low grade to the high grade in Xuanzhou district and Jingde county, but ranged from from the middle grade to the high grade in Langxi county and Jing county.

\subsection{Evaluation of Contents of Tobacco-Planting Topsoil Available Fe, Mn, Cu and $\mathrm{Zn}$ in 2015}

Table 6 shows the sample number distribution in various grades of tobacco-planting topsoil available $\mathrm{Fe}, \mathrm{Mn}, \mathrm{Cu}$ and $\mathrm{Zn}$.

Table 6 shows that to total Xuancheng city, no tobacco-planting topsoil samples was in the low grade of available Fe, while only $3(2.41 \%)$ were in the middle grade, 14 (11.29\%) and 109 (87.90\%) of tobacco-planting topsoil samples were in the low and middle grades of available $\mathrm{Mn}$, respectively. no tobacco-planting

Table 5. Statistic information of topsoil available $\mathrm{Fe}, \mathrm{Mn}, \mathrm{Cu}$ and $\mathrm{Zn}$ of tobacco-planting farmlands in Xuancheng in $2015\left(\mathrm{mg} \cdot \mathrm{kg}^{-1}\right)$.

\begin{tabular}{lcccccc}
\hline \multirow{2}{*}{ Microelement contents } & $\begin{array}{c}\text { Xuanzhou } \\
\text { district }\end{array}$ & $\begin{array}{c}\text { Langxi } \\
\text { county }\end{array}$ & $\begin{array}{c}\text { Jingde } \\
\text { county }\end{array}$ & $\begin{array}{c}\text { Jing } \\
\text { county }\end{array}$ & Total \\
\hline \multirow{2}{*}{$\mathrm{Fe}$} & Range & $5.1-35.4$ & $24.5-36.0$ & $28.2-37.6$ & $17.9-36.5$ & $5.1-37.6$ \\
& Mean/S.D. & $28.3 / 6.4$ & $32.0 / 2.6$ & $34.4 / 2.2$ & $31.7 / 4.0$ & $31.1 / 5.1$ \\
$\mathrm{Mn}$ & Range & $1.5-12.8$ & $4.9-15.7$ & $3.1-13.0$ & $1.7-13.2$ & $1.5-15.7$ \\
& Mean/S.D. & $9.3 / 3.5$ & $10.0 / 2.7$ & $10.8 / 2.7$ & $9.3 / 3.6$ & $9.8 / 3.2$ \\
$\mathrm{Cu}$ & Range & $0.4-3.9$ & $0.8-3.0$ & $0.6-7.6$ & $0.3-4.4$ & $0.3-7.6$ \\
& Mean/S.D. & $1.6 / 0.9$ & $2.1 / 0.4$ & $2.6 / 1.3$ & $2.5 / 1.0$ & $2.1 / 1.0$ \\
$\mathrm{Zn}$ & Range & $0.2-4.1$ & $0.6-2.0$ & $0.4-3.2$ & $0.8-4.8$ & $0.1-2.0$ \\
& Mean/S.D. & $1.9 / 0.8$ & $1.3 / 0.4$ & $2.0 / 0.9$ & $1.9 / 0.8$ & $0.3 / 0.2$ \\
\hline
\end{tabular}


Table 6. Numbers of farmlands under different grades of tobacco-planting topsoil available $\mathrm{Fe}, \mathrm{Mn}, \mathrm{Cu}$ and $\mathrm{Zn}$ in Xuancheng in 2007.

\begin{tabular}{ccccccccccccc}
\hline \multirow{2}{*}{ Region } & \multicolumn{3}{c}{ Available Fe } & \multicolumn{3}{c}{ Available Mn } & \multicolumn{3}{c}{ Available Cu } & \multicolumn{2}{c}{ Available Zn } \\
\cline { 2 - 11 } & Low & Middle & High & Low & Middle & High & Low & Middle & High & Low & Middle High \\
\hline Xuanzhou & 0 & 3 & 43 & 8 & 38 & 0 & 0 & 18 & 28 & 2 & 4 & 40 \\
Langxi & 0 & 0 & 27 & 1 & 25 & 1 & 0 & 1 & 26 & 0 & 6 & 21 \\
Jingde & 0 & 0 & 27 & 2 & 25 & 0 & 0 & 2 & 25 & 1 & 5 & 21 \\
Jin & 0 & 0 & 24 & 3 & 21 & 0 & 0 & 3 & 21 & 0 & 3 & 21 \\
Total & 0 & 3 & 121 & 14 & 109 & 1 & 0 & 24 & 100 & 3 & 18 & 103 \\
\hline
\end{tabular}

topsoil samples was in the low grade of available $\mathrm{Cu}$, while $24(19.35 \%)$ were in the middle grade. $3(2.42 \%)$ and 18 (14.52\%) of topsoil samples were in the low and middle grades of available $\mathrm{Zn}$, respectively. The above data also suggest most of tobacco-planting farmlands were sufficient in $\mathrm{Fe}$ and $\mathrm{Cu}$ nutrients, no need for applying $\mathrm{Fe}$ and $\mathrm{Cu}$ fertilizers, but a few of farmlands in Xuanzhou district (8 farmlands, $17.39 \%$ of its total tobacco-planting farmlands), langxi (1 farmland, $3.70 \%$ of its total tobacco-planting farmlands), Jingde county (2 farmlands, $7.41 \%$ of its total tobacco-planting farmlands) and Jing county (3 farmlands, $12.50 \%$ of its total tobacco-planting farmlands) were in $\mathrm{Mn}$ and $\mathrm{Zn}$ deficiency and should applying $\mathrm{Mn}$ and $\mathrm{Zn}$ fertilizers.

\subsection{Discussion on Changes of Topsoil Available Fe, $\mathrm{Mn}, \mathrm{Cu}$ and $\mathrm{Zn}$}

According to the historical data ${ }^{2}$, topsoil available $\mathrm{Fe}, \mathrm{Mn}, \mathrm{Cu}$ and $\mathrm{Zn}$ in the farmlands in Xuancheng were $70.8 \mathrm{mg} \cdot \mathrm{kg}^{-1}, 7.0 \mathrm{mg} \cdot \mathrm{kg}^{-1}, 2.2 \mathrm{mg} \cdot \mathrm{kg}^{-1}$ and 1.9 $\mathrm{mg} \cdot \mathrm{kg}^{-1}$, respectively, they increased by $33.14 \%, 64.29 \%, 51.11 \%$ and $36.67 \%$ in 2008 respectively. However, topsoil available $\mathrm{Fe}, \mathrm{Mn}, \mathrm{Cu}$ and $\mathrm{Zn}$ in the tobacco-planting farmland decreased by $70.63 \%, 50.00 \%, 53.33 \%$ and $90.00 \%$ compared with those of the farmland in 2015. The increases from 1980s to 2008 and the decrease from 2008 to 2015 both are significant. Particularly the latter should be more concerned for tobacco planting.

The reasons for the above changes could be concluded as that during 1980s-1990s the positive effects of microelement in promoting the yields and qualities of plants were gradually disclosed and realized, which once led the large amount of microelement fertilizers were produced and applied widely in China because crop farming was the dominant source of the family income at that time, it was also the reason for the overall great increases in available $\mathrm{Fe}, \mathrm{Mn}, \mathrm{Cu}$ and $\mathrm{Zn}$ in the farmlands in Xuancheng from 1980s to 2008. However, with the rapid development of the social economy, the family income of the local farmers is diversified which are mainly from non-agricultural activities, the attention of the local famers on the fertilizers for increasing crop yields and qualities has re-

${ }^{2}$ Soil Survey Office \& Soil Fertilization Station of Xuanzhou. Xuanzhou Soil (unpublished data), 1987. 
duced greatly and widely, which results in the decrease in applying microelement fertilizers.

Other study showed that the average data (120 farmlands) of topsoil available $\mathrm{Fe}, \mathrm{Mn}$ and $\mathrm{Cu}$ and $\mathrm{Zn}$ in the farmlands of south Anhui were $157.3 \mathrm{mg} \cdot \mathrm{kg}^{-1}, 37.0$ $\mathrm{mg} \cdot \mathrm{kg}^{-1}, 2.6 \mathrm{mg} \cdot \mathrm{kg}^{-1}$ and $1.2 \mathrm{mg} \cdot \mathrm{kg}^{-1}$, respectively [21], and compared with our data in 2015, which are $49.5 \%$ and $88.8 \%$ higher in Fe and Mn while $42.2 \%$ and $60.0 \%$ lower in $\mathrm{Cu}$ and $\mathrm{Zn}$. respectively, and these differences may be attributed to the differences in the sampling time and sites.

For the input and output of microelements in the farmland under tobacco-rice rotation, the exogenous available $\mathrm{Fe}, \mathrm{Mn}, \mathrm{Cu}$ and $\mathrm{Zn}$ usually are input into the farmland topsoil by fertilization, and no $\mathrm{Fe}, \mathrm{Mn}$ and $\mathrm{Cu}$ has input into the farmland soils by fertilization for they are thought plentiful in the topsoil except $\mathrm{Zn}$ which may possibly contained in the compound fertilizer for tobacco-planting farmland, but no accurate information of the applied amount is available, so here we adopted the recommended applying amount $\mathrm{Zn} 0.25$ $\mathrm{kg} \cdot \mathrm{hm}^{-2}$ as the annual input into the topsoil of farmland [22]. Available Fe, Mn, $\mathrm{Cu}$ and $\mathrm{Zn}$ usually are carried out of the farmland by harvest of tobacco and rice. In Xuancheng tobacco leaves are harvested and tobacco stems usually are removed out from the tobacco fields to avoid disease spread. According to measured data of in total 62 tobacco samples collected from Xuancheng during 2007-2008, the average concentrations of $\mathrm{Fe}, \mathrm{Mn}, \mathrm{Cu}$ and $\mathrm{Zn}$ are $0.15 \mathrm{~g} \cdot \mathrm{kg}^{-1}, 0.18$ $\mathrm{g} \cdot \mathrm{kg}^{-1}, 0.01 \mathrm{~g} \cdot \mathrm{kg}^{-1}$ and $0.08 \mathrm{~g} \cdot \mathrm{kg}^{-1}$, respectively with the total biomass of 4500 $\mathrm{kg} \cdot \mathrm{hm}^{-2}$, thus, about $0.68 \mathrm{~kg} \cdot \mathrm{hm}^{-2}$ of $\mathrm{Fe}$, about $0.81 \mathrm{~kg} \cdot \mathrm{hm}^{-2}$ of Mn, about 0.05 $\mathrm{kg} \cdot \mathrm{hm}^{-2}$ of $\mathrm{Cu}$, about $0.36 \mathrm{~kg} \cdot \mathrm{hm}^{-2}$ of $\mathrm{Zn}$ are moved out annually from the farmland by tobacco leaves and stems. The average concentrations of $\mathrm{Fe}, \mathrm{Mn}, \mathrm{Cu}$ and $\mathrm{Zn}$ are $0.007 \mathrm{~g} \cdot \mathrm{kg}^{-1}, 0.004 \mathrm{~g} \cdot \mathrm{kg}^{-1}, 0.004 \mathrm{~g} \cdot \mathrm{kg}^{-1}$ and $0.013 \mathrm{~g} \cdot \mathrm{kg}^{-1}$ in rice ears [23] with the total biomass of $7500 \mathrm{~kg} \cdot \mathrm{hm}^{-2}$, then about $0.05 \mathrm{~kg} \cdot \mathrm{hm}^{-2}$ of $\mathrm{Fe}, 0.03$ $\mathrm{kg} \cdot \mathrm{hm}^{-2}$ of $\mathrm{Mn}, 0.03 \mathrm{~kg} \cdot \mathrm{hm}^{-2}$ of $\mathrm{Cu}$, and $0.10 \mathrm{~kg} \cdot \mathrm{hm}^{-2}$ of $\mathrm{Zn}$ are moved out annually from the farmland by rice ears, Thus, in total, about $0.73 \mathrm{~kg} \cdot \mathrm{hm}^{-2}$ of $\mathrm{Fe}$, $0.84 \mathrm{~kg} \cdot \mathrm{hm}^{-2}$ of $\mathrm{Mn}, 0.08 \mathrm{~kg} \cdot \mathrm{hm}^{-2}$ of $\mathrm{Cu}$, and $0.46 \mathrm{~kg} \cdot \mathrm{hm}^{-2}$ of $\mathrm{Zn}$ are carried out of the farmland. So the net annual decreases of available $\mathrm{Fe}, \mathrm{Mn}, \mathrm{Cu}$ and $\mathrm{Zn}$ in the farmland topsoil are about $0.73 \mathrm{~kg} \cdot \mathrm{hm}^{-2}$ of $\mathrm{Fe}, 0.84 \mathrm{~kg} \cdot \mathrm{hm}^{-2}$ of $\mathrm{Mn}, 0.083$ $\mathrm{kg} \cdot \mathrm{hm}^{-2}$ of $\mathrm{Cu}$, and $0.21 \mathrm{~kg} \cdot \mathrm{hm}^{-2}$ of $\mathrm{Zn}$, respectively. Thus, for the farmland with the rotation of tobacco-rice, it is necessary to monitor the dynamic changes of microelements in time in order to decide whether applying the microelement fertilizers or not.

\section{Conclusion}

Our survey showed that there were great increases in topsoil available $\mathrm{Fe}, \mathrm{Mn}$, $\mathrm{Cu}$ and $\mathrm{Zn}$ of the farmlands mainly under rice-rice rotation in Xuancheng city from 1980s to 2008 due to the historic intensive and overall application of microelement fertilizers, but significant decrease in topsoil available $\mathrm{Fe}, \mathrm{Mn}, \mathrm{Cu}$ and $\mathrm{Zn}$ of the farmlands under tobacco-rice rotation due to the net deficiency in 
the input and output of microelements. It is necessary to monitor the farmland dynamically and in time in order to decide whether applying microelement fertilizers or not.

\section{Acknowledgements}

This study was supported by the Program of Anhui Branch of China National Tobacco Co. (20150551009), the External Operation Program of BIC, Chinese Academy of Sciences (151432KYSB2015007), and the Intergovernmental Special Program of National Key R \& D Plan (2016YFE0112700) and Sino-EU Cooperation Programme iSQAPER. We also thank the supports and help from the Soil and Fertilization Station of Xuancheng in data supply and field sampling activity.

\section{References}

[1] Liu, Z. (1996) Microelements in Soils of China. Jiangsu Science and Technology Press, Nanjing.

[2] Xing, G.X. and Zhu, J.G. (2003) Chemistry of Soil Micro \& Rare-earth Elements. Science Press, Beijing.

[3] Wang, D.S., Liu, G.S. and Li, Z.H. (2002) Tobacco Cultivation. China Science and Technology Press, Hefei.

[4] Li, M.D., Xiao, H.Q., Yu, C.X., et al. (2005) Status of Medium and Minor Elements in Hunan Province and Effectiveness of Fertilizer Application in Tobacco Plants. Chinese Tobacco Science, No. 1, 25-27.

[5] Liu, G.S., Wang, P., Duan, S.J., et al. (2009) Effect of Adding Trace Element Fertilizer or Biofertilizer on the Chemical Quality of Flue-Cured Tobacco. Journal of Henan Agricultural University, 43, 241-246.

[6] Xu, X.Q., Xu, A.F. and Wang, W.G. (2012) Effects of Micro Elements of Tobacco Leaves on the Aroma Quality of Flue-Cured Tobacco. Guangdong Agricultural Sciences, No. 3, 30-34.

[7] Song, M. and Zhao, W.P. (2012) Effects of Several Kinds of Trace Element Fertilizers on Yield and Quality of Flue-Cured Tobacco. Beijing Agriculture, No. 5, 92-93.

[8] Zeng, R., He, Z.J., Cheng, Z.M., et al. (2010) Study on Effects of Cu on Tobacco Growth and Yield. Modern Agricultural Sciences and Technology, 2010, 65-66.

[9] Wang, Y.Y. (2013) Distribution Characteristics of Fe, Mn, Cu, Zn Contents in Soil and Tobacco Leaves of Typical Tobacco Planting Area. Chinese Academy of Agricultural Sciences, Beijing.

[10] Zhao, X.B. (2013) Content Distribution and Space Variation of Trace Elements in Tobacco-Planting Soil in Changshun County of Guizhou Province. Guizhou Agricultural Sciences, 41, 68-71.

[11] Gu, H.S., La, H.X., Cao, T.M., et al. (2012) Spatial Variability of Microelement Content in Karst Tobacco-Growing Regions Using Geostatistics and GIS-A Case Study in Bijie of Guizhou Province. Journal of Henan Agricultural Sciences, 41, 74-78.

[12] Liu, C.K., Tang, S.K., Zhang, T., et al. (2012) Study on Spatial Distribution of Available Microelement in Soil in Luliang Tobacco Farming Area. Chinese Agricultural Science Bulletin, 28, 71-75.

[13] Li, Q., Zhou, J.H., Zhang, Y.A., et al. (2013) Spatial Variability and Influencing Fac- 
tors of Available Microelements in Tobacco Growing Soils in Qujing. Tobacco Science \& Technology, No. 10, 63-67, 69.

[14] Cui, A.H., Zhan, D.Q., Guo, L., et al. (2014) Microelement Contents in Plough Horizons of Tobacco Planting Soil in Bozhou. Soils, 46, 1164-1168.

[15] Ji, X.J., Shen, S.D., Xue, L., et al. (2013) Soil Taxonomy of Typical Tobacco Fields in Xuancheng of Southern Anhui. Soils, 45, 763-765.

[16] Anhui Bureau of Quality and Technical Supervision (2006) Technical Regulations on Normalized Transplanting of High Quality Flue-Cured Tobacco in Xuancheng.

[17] Lu, R.K. (1999) Methods of Soil Agricultural Chemistry Analyses. China Agriculture Press, Beijing.

[18] Bao, S.D. (2005) Soil Agricultural Chemistry Analyses. China Agriculture Press, Beijing.

[19] Hu, H.J., Wan, S.H., He, X.Y., et al. (2014) Brief Study on Influential Factors of Availability of Soil Cu, Fe, Mn and Zn. Agriculture and Technology, 34, 23-24.

[20] ISSAS, CTC and SQM (1993) Atlas of Flue-Cured Tobacco Nutrition and Disorder Symptoms. Jiangsu Science and Technology Press, Nanjing.

[21] Wang, S.J., Li, T., Zhao, D.K., et al. (2005) Study on Middle- and Microelement Contents in Soils and Tobacco Leaves in Anhui Tobacco-Planting Regions. Journal of Anhui Agricultural Sciences, 33, 2065-2066.

[22] Liu, C.S. and Wang, H.J. (1988) Suitable Applying Amounts for Microelements. Northern Horticulture, No. 1, 43.

[23] Guo, Y.M., Li, H.H., Li, S.M., et al. (2013) Correlation Analysis of Protein Content and Mineral Content in Brown Rice and Establishment of the Math Model for the NIRS Analysis. Journal of Plant Genetic Resources, 14, 173-178. 